\title{
Tæt på døden
}

Tidsskrift for Forskning i Sygdom og Samfund

Nr. 12, 2010 


\title{
Tidsskrift for Forskning i Sygdom og Samfund
}

\author{
Nr. 12: Tæt på døden
}

(C) 2010 forfatterne og udgiverne.

Redaktion:

Mette Bech Risør (ansv.), Forskningsklinikken for Funktionelle Lidelser, Århus Sygehus

Torsten Risør, Forskningsenheden for Almen Praksis, Aarhus Universitet

Gitte Wind, VIA University College, Århus

Lotte Meinert, Institut for Antropologi og Etnografi, Aarhus Universitet

Marianne Rosendal, Forskningsenheden for Almen Praksis, Aarhus Universitet

Peter Vedsted, Forskningsenheden for Almen Praksis, Aarhus Universitet

Ann Dorrit Guassora, Forskningsenheden for Almen Praksis, Københavns Universitet

Susanne Reventlow, Forskningsenheden for Almen Praksis, Københavns Universitet

Gxsteredaktør:

Mette Asbjørn Neergaard, Forskningsenheden for Almen Praksis, Aarhus Universitet

Peer review foretages af et tværvidenskabeligt panel bestående af bl.a. læger, antropologer, filosoffer, historikere, psykologer og sociologer.

Proof: Thomas Christian Mikkelsen.

Layout og prepress: Jens Kirkeby, Aarhus Universitet, Moesgård.

Tryk: Werks Offset, Højbjerg.

Udgiver:

Foreningen Medicinsk Antropologisk Forum,

Afd. for Antropologi og Etnografi, Aarhus Universitet, Moesgård, 8270 Højbjerg.

Bestilling, abonnement, henvendelser og hjemmeside:

Tidsskrift for Forskning i Sygdom og Samfund.

Afd. for Antropologi og Etnografi, Aarhus Universitet, Moesgård, 8270 Højbjerg

Torsdag kl. 9-12, tlf. 89424597, email: sygdomogsamfund@hum.au.dk

www.sygdomogsamfund.dk

ISSN: 1604-3405

Tidsskriftet er udgivet med støtte fra Forskningsrådet for Kultur og Kommunikation.

Formål:

Tidsskrift for Forskning i Sygdom og Samfund er et tværfagligt tidsskrift, der tager udgangspunkt i medicinsk antropologi. Tidsskriftet har til formål at fremme og udvikle den forskning, der ligger i grænsefeltet mellem sundhedsvidenskab og humaniora/samfundsvidenskab. Tidsskriftets målsætning er at fungere som et forum, hvor disse fag kan mødes og inspirere hinanden - epistemologisk, metodisk og teoretisk - i forskellige forskningssammenhænge. Tidsskriftet formidler den debat og teoretiske udvikling, der foregår i de voksende faglige samarbejds- og forskningsinitiativer, der udspringer af dette grænsefelt. Tidsskriftet henvender sig til alle med interesse for forskning i sygdom og samfund og i særlig grad til sundhedsmedarbejdere i forsknings- og undervisningssammenhæng med forbindelse til tværfaglige miljøer.

\section{Aims and scopes}

The Journal for Research in Sickness and Society is an interdisciplinary journal which has a theoretical background in medical anthropology. The aim and purpose of the journal is to promote and develop research in the borderland between the health sciences and the humanities/the social sciences. The goal of the journal is to function as a forum in which these disciplines may meet and inspire each otherepistemologically, methodologically and theoretically. The journal conveys the debate and theoretical development which takes place in the growing collaboration and research initiatives emerging from this borderland. The journal addresses all with an interest in research in sickness and society and especially health professionals working with education and/or research in interdisciplinary institutions. 


\section{Indhold}

Mette Asbjørn Neergaard og Marianne Rosendal Introduktion 5

Tove Vejlgaard Indsatsen overfor alvorligt syge og døende set fra et sundhedsfagligt perspektiv 11

Michael Hoiid Jacobsen

Thanatosociologi - træk af en udviklingshistorik og tilstandsrapport 23

Marie Konge Nielsen

Det gode liv før døden 51

Susan Rydahl-Hansen

Lidelsens udtryksformer og vilkår - som beskrevet af uhelbredeligt kræftsyge patienter 75

Mette Raunkixr

At tale om døden - forskelle og ligheder mellem konteksten plejehjem og eget hjem 97

Niels Christian Hvidt

Patienters tro på guddommelig indgriben ved livstruende sygdom - en positiv eller en negativ ressource? 119

Cecilie Rubow og Christine Tind Johannessen-Henry

Variationer af liv i døden: Transcendenser i hverdagslivets (nye) polydoksi 135

Mai-Britt Guldin

De store teoriers fald. Træk af sorgteori gennem tiden 155

Abstracts in English 175

Forfatterliste 181

Skrivevejledning 185

Beskrivelse af nummer 13188 


\title{
Oversigtsartikel
}

\section{Thanatosociologi \\ - træk af en udviklingshistorik og tilstandsrapport}

\section{Michael Hviid Jacobsen}

Aalborg Universitet, mhj@socsci.aau.dk

Jacobsen, M.H. (2010). Thanatosociologi - træk af en udviklingshistorik og tilstandsrapport. Tidsskrift for Forskning i Sygdom og Samfund, nr. 12, 23-49.

\author{
Der Tod ist groß, \\ Wir sind die Seinen, \\ Lachenden Munds. \\ Wenn wir uns mitten im Leben meinen, \\ Wagt er zu weinen, \\ Mitten in uns \\ - Rainer Maria Rilke
}

\begin{abstract}
Denne artikel introducerer til den ofte oversete sociologiske subdisciplin, der bærer titlen 'thanatosociologi', og som er optaget af at beskrive og analysere menneskers forhold til døden samt at belyse de historiske, kulturelle og sociale omstændigheder, hvorunder døden udspiller sig. Artiklens hensigt er for det første at præsentere læseren for formålet med og indholdet af thanatosociologiens blik på døden med særligt fokus på, hvordan thanatosociologiens udvikling afspejler forandringer $i$ samfundets forhold til døden og vice versa. Thanatosociologien er således $i$ vid udstrækning opstået som en reaktion på den måde, døden opfattes og håndteres på $i$ det moderne vestlige samfund, samtidig med at thanatosociologien selv har påvirket denne udvikling. For det andet er det hensigten kronologisk at dokumentere fremvæksten af thanatosociologien gennem det 20. århundrede og vise dens variationer og forandringer. Slutteligt diskuteres det, hvilke faglige udfordringer der lurer for en fortsat udvikling af thanatosociologien.
\end{abstract}




\section{Mod en sociologi om døden}

Normalt når vi tænker på eller taler om 'samfundet', så består det af levende mennesker, der bevæger sig rundt mellem hinanden, lever livet, trækker vejret, planlægger deres fremtid og i det hele taget er optaget af alt andet end døden. For efterhånden længe siden konstaterede Peter L. Berger imidlertid hvordan "samfundet består af mænd og kvinder, der i forening konfronteres med døden « (Berger 1969:52). Fællesnævneren for alle mennesker er nemlig ikke bare livet, men også døden og samfundet udgøres således ikke bare af liv og levende mennesker - samfundet består også af død, døende mennesker, efterladte mennesker, opfattelser og forestillinger om død og udødelighed, følelsen af at dø, at miste og at mindes. Derfor må den videnskab der er optaget af at studere samfundet - og sociologien er netop pr. definition 'videnskaben om samfundet' - nødvendigvis også interessere sig for døden, fordi døden er en iboende del af livet, uanset om vi kan lide det eller ej. Troen på muligheden for at skabe et samfund hvor ingen længere dør, som den portugisiske nobelprismodtager José Saramago ellers beskriver i Døden udebliver indimellem (2008), kan således ligge på et meget lille sted.

Til trods herfor har sociologien dog ikke været synderligt optaget af døden i en efterhånden længere årrække og en af forklaringerne kan være, at sociologien som et produkt af den fremvoksende modernitet, ligesom det moderne samfund selv fornægtede og fortrængte døden (Mellor \& Shilling 1993; Willmott 2000). Døden var en del af den 'erfaringens afsondring' af eksistentielle forhold som sygdom, afgivelse, vanvid og ikke mindst netop død som modernitetens værdier og institutioner understøttede. Men døden vendte tilbage - som i Sigmund Freuds opfattelse af 'det fortrængtes tilbagekomst' kan fortrængning kun opretholdes for en vis stund, hvorefter det der fortrænges og afsondres, på ny trænger gennem den porøse skorpe, der har holdt det tilbage. Døden udgør således arketypen på Freuds 'det uhyggelige' der trods en ihærdig indsats på fortrængning alligevel finder vej tilbage til den virkelighed, hvorfra det ellers blev forsøgt skjult (Freud 1919/1998). ${ }^{1}$

Som konsekvens heraf tyder meget således på at vi netop i disse år, med opkomsten af et senmoderne samfund som en ny epoke i modernitetens udviklingshistorie, oplever en særlig interesse for at forske i døden inden for sociologien og en lang række andre beslægtede samfundsvidenskabelige discipliner, der afspejler at døden ikke længere kan eller bør afsondres fra det øvrige samfundsliv (Giddens 1996). Det er som om at sociologien og andre samfundsvidenskaber efterhånden har taget indsigten fra Villy Sørensen til sig om, at 'der er liv i døden, og der er 
død i livet, men der er formentlig mest liv i livet, hvis døden er en del af det'. Men fordi døden er et almenmenneskeligt og universelt livsvilkår er den også, som indledningscitatet af Rainer Maria Rilke angiver, et umådeligt stort, komplekst og vanskeligt overskueligt fænomen at indfange og begribe, og derfor fordrer det et særligt sindelag og en særligt veludviklet sociologisk sensitivitet, interesse og sans at forsøge at forstå og forklare dødens samfundsmæssige betydning. Selvom ingen formentlig vil benægte at døden er et faktum, der påvirker vores liv, er der dog stadig kun relativt få, der har formået at gøre denne viden til sociologisk indsigt. Dette kan være en af årsagerne til, som jeg skal vise senere, at døden igennem en længere årrække har været fraværende i sociologien.

Udviklingen hen mod en stigende interesse for døden som et legitimt og frugtbart forskningsfelt i sociologien har således været længe undervejs, som jeg skal vise senere i denne artikel. Det er som om at såvel samfund som samfundsvidenskab (herunder sociologi) først efter årtier med dødstabu, fortrængningsmekanismer og kulturel distance til døden var klar til at tage døden alvorligt - tage døden til sig. Der er dog mange gode grunde til at forske i døden med en sociologisk optik. Thanatosociologien, eller dødssociologien som den også mindre eksotisk betegnes i dele af litteraturen, ${ }^{2}$ kan i den forbindelse fungere som en slags camera obscura - det fotografiske apparat, hvor lys, der placeres bag et objekt, lukkes ind igennem en lille åbning i den ene ende af en boks, hvorefter lyset kastes ned i den anden ende af boksen, hvorfra der så projiceres et skarpt men omvendt billede af det oprindelige objekt. På tilsvarende måde kan thanatosociologien gennem en slags omvendt optik med et fokus på døden stille skarpt på en lang række aspekter af vores forhold til og udlevelse af livet og dermed bidrage til en øget forståelse af mange af livets øvrige facetter, som døden nødvendigvis er en iboende del af. Dødens sociologi, eller thanatosociologien, er således ikke optaget af at studere døden i sig selv, men af døden som en del af livet - som et spejlbillede på livet.

Sociologien er i sig selv en hybridvidenskab der i starten af det 19. århundrede udsprang af inspiration fra såvel naturvidenskabelig metode som skønlitterær samfundsdiagnose for siden at skabe sig sin egen særegne fagstatus (Lepenies 1988). Der findes som konsekvens heraf mange forskellige opfattelser af og definitioner på sociologien fra de mest formelle til de mere folkelige. Det er min opfattelse, som bygger på den polsk-engelske sociolog Zygmunt Bauman, at sociologien måske mest retvisende kan defineres som en 'dialog med og kommentering på den menneskelige erfaring', og en af de mest gennemgribende, definitive og uafvendelige menneskelige erfaringer er netop erfaringen af og med døden - dødeligheden har til alle tider i alle samfund været og vedbliver formentlig med stadig 
at være 100 \%. Thanatosociologien er således den subdisciplin - på højde med mange andre subdiscipliner som barndomssociologi, ungdomsforskning eller social gerontologi - inden for sociologien, der interesserer sig specifikt for studiet af det almenmenneskelige grundvilkår, døden, og ligesom moderdisciplinen, sociologien, forsøger den således at indfange den menneskelige erfaring af og med døden.

Døden har ellers igennem århundreder fortrinsvis været forbeholdt lægevidenskabens domæne, der søgte efter en løsning på livets og dødens mysterium, eller teologiens domæne, der søgte at tilbyde et bolværk mod døden i religiøse forestillinger og trosopfattelser. Men hvor lægevidenskaben er optaget af de fysisk-medicinske forhold omkring døden, og teologien ønsker at give svar på livets mening midt i dødens meningsløshed, er thanatosociologien derimod fortrinsvis optaget af at studere dens sociale og kulturelle aspekter. En bred men ikke desto mindre forholdsvis anvendelig definition på thanatosociologi (thanatos betyder død på græsk) kunne derfor lyde:

Thanatosociologi interesserer sig for de sociale og kulturelle forestillinger, betydninger, konstruktioner og håndteringer, der udfoldes i forhold til døden i samfundet, uanset karakteren heraf. Thanatosociologien er således optaget af at dokumentere, beskrive, analysere, fortolke og forstå dødens forskellige fremtrædelsesformer og betydninger uden nødvendigvis at vurdere dem i normativ eller moralsk henseende. ${ }^{3}$

Thanatosociologi interesserer sig samtidig for at forstå og forklare forandringer og forskydninger i de holdninger og handlinger, der knytter sig til døden i et givent samfund eller på tværs af samfund. Derfor er inddragelsen af et historisk-komparativt perspektiv ofte en vigtig komponent $i$ thanatosociologien for derved at sætte samtidens/samfundets dødsopfattelse og dødshåndtering i relief.

Thanatosociologien, der også fra tid til anden mere bredt betegnes 'thanatologi', er et relativt uoverskueligt og mangfoldigt felt, der vanskeligt lader sig afgrænse, og som på mange måder lapper over med, inspireres af og påvirker andre tilsvarende subdiscipliner inden for historievidenskab, filosofi, antropologi og psykologi. Ligesom moderdisciplinen er thanatosociologien også en hybridvidenskab der trækker på en lang række forskellige discipliner og fagområder. Den befinder sig således i krydsfeltet mellem kulturanalyse, sociologi, socialfilosofi, antropologi, psykologi, historie og praktisk sygepleje 
og der trækkes relativt frit på indsigter, teorier og erfaringer fra alle disse felter. Den australske sociolog Allan Kellehear (2007) karakteriserede for nylig thanatosociologien som et felt der internt var opdelt mellem på den ene side de store anerkendte sociologer (som Zygmunt Bauman, Anthony Giddens, Norbert Elias og Jean Baudrillard), der med et generelt, abstrakt og distanceret teoretisk blik analyserede forandringen i vores forhold til døden, og på den anden side de empirisk-orienterede sociologer, der med fokus på detaljen og med nærhed til praksis er optaget af kommunikation om og håndtering af døden i mere mikrosociale sammenhænge. Det var Kellehears konklusion at der mellem disse to grupper hersker begrænset kommunikation eller meget lidt vekselvirkning og vidensudveksling. Selvom jeg er enig $i$ at det thanatosociologiske felt er et opdelt domæne mellem generalister på den ene side og specialister på den anden, så mener jeg imidlertid ikke, at dette udgør et problem. Ligesom $i$ andre discipliner og subdiscipliner er det også vigtigt $i$ thanatosociologien at der er rum til en mangfoldighed af teoretiske indsigter og metodiske tilgange, og ligesom det er vigtigt, at der udarbejdes generelle teoretiske skabeloner til at indfange konturerne af en kompleks udviklingshistorie og samtidsdiagnose, er det vigtigt at der udføres konkret empirisk forskning på såvel mikro- som makroplan. Denne rummelighed i og elasticitet af thanatosociologien er netop et af feltets største styrker.

Efter denne korte introduktion til thanatosociologien vil det følgende være et forsøg på at tegne konturerne af thanatosociologiens interessefelter, teoridannelser, empiriske fund og udviklingsforløb over tid. Dette er derfor en kronologisk opbygget artikel, hvor jeg først forsøger at tegne konturerne af thanatosociologiens udvikling og dagsordener over det seneste halve århundrede og afslutningsvis vil forsøge at påpege nogle af de udfordringer thanatosociologer fremover vil skulle konfrontere, og de målsætninger, man kan arbejde hen imod. Formålet med artiklen er således at bibringe læseren et overblik over thanatosociologien som felt eller subdisciplin samt angive mulige nutidige og fremtidige områder som fordrer thanatosociologisk opmærksomhed.

\section{Før 1950: Den fraværende død}

Thanatosociologiens grundlæggelse lader sig vanskeligt datere præcist. Imidlertid har der i årenes løb, ligesom med mange andre sociologiske subdiscipliner så som eksempelvis barndomssociologi, bysociologi, uddannelsessociologi, afvigel- 
sessessociologi eller følelsessociologi, siden midten af det 20. århundrede været tale om en gradvis vækst og ekspansion, hvis årsager formentlig skal lokaliseres i sociologiens - såvel som andre videnskabsdiscipliners - tiltagende faglige specialisering og funktionelle differentiering. De første mange årtier af det 20 . århundrede var der dog i vid udstrækning tale om total tavshed omkring eller manglende opmærksomhed mod døden som en relevant eller passende tematik for sociologien, og thanatosociologien er således en relativt ung subdisciplin $\mathrm{i}$ sociologisk sammenhæng. Naturligvis har der været skrevet om døden i ny og næ, men mere systematiske studier, underbyggede teorier eller udførlige undersøgelser og perspektiver så først dagens lys fra midten af 1960'erne, som vi skal se senere.

Det første studium i sociologien, der satte mere end blot sporadisk fokus på døden, så dagens lys i slutningen af 1800-tallet. Det var den franske sociolog Émile Durkheims undersøgelse af selvmord i Suicide (Durkheim 1897/1951). I denne bog udviklede Durkheim på baggrund af bl.a. statistisk materiale om ægteskabsstatus og religiøst tilhørsforhold en typologi over selvmordsformer der i vid udstrækning var betinget af, i hvilket omfang man var integreret i samfundet, og hvorvidt reguleringen i samfundet var høj eller lav. Durkheim kaldte de forskellige typer af selvmord for henholdsvis fatalistisk, anomisk, egoistisk og altruistisk og den relative udbredelse af disse selvmordsformer kunne fortælle noget om samfundets generelle tilstand. Durkheim lokaliserede således ikke forklaringer på selvmord på aktørniveau - altså hvorfor det enkelte menneske valgte at begå selvmord - og han afviste således Gabriel Tardes imitationsteori, men forklaringen skulle derimod findes på samfundsniveau. Andetsteds, i sin bog The Elementary Forms of Religious Life, hvor Durkheim analyserede på antropologisk indsamlet materiale blandt australske stammefolk, berørte han også døden, herunder hvilken betydning døden spillede i totemistiske ritualer, og hvilken rolle dødsfald havde for det lokale stammefællesskab. Han skrev bl.a.: “Når nogen dør, vil den gruppe, hvortil han hører, føle sig reduceret, og den vil, for at modvirke dette tab, forsamles. Kollektive følelser fornys, der fører til, at mennesker søger mod hinanden og mødes« (Durkheim 1915:339). Ved dødsfald trues fællesskabet kortvarigt og det er derfor funktionelt med kollektive ritualer, der kan skabe fornyet sammenhold. Andre steder i bogen er Durkheim optaget af døden som når han beskriver forbud omkring kontakt til døden og den afdøde, troen på udødelighed og adskillelsen af krop og sjæl. Perspektivet i Durkheims funktionalistiske udlægning af døden er mestendels rettet mod hvordan dødsfald udgør en trussel mod den sociale sammenhængskraft, og hvordan man gennem kollektive ritualer og ceremonier for- 
mår at genbekræfte sammenholdet og fællesskabet, men hans fokus på døden forblev ikke desto mindre forholdsvis fragmentarisk.

Også hos en anden sociologisk klassiker, den tyske sociolog Max Weber, der i modsætning til Durkheims kollektivistiske perspektiv var aktørorienteret, er døden tilstede, om end på en om muligt endnu mere sporadisk måde. Døden optræder i Webers forfatterskab i forbindelse med de religionsociologiske studier, der omhandler kapitalismens fremvækst i den vestlige verden og i hans belysning af betydningen af den protestantiske etik i den forbindelse. Weber mente, at særligt den puritanske livsførelse, askesen og troen på prædestination, som kendetegnede calvinismen, var en vigtig katalysator i kapitalismens udvikling og konsolidering i Vesten. I særlig grad var det netop troen på, og en vedvarende søgen efter tegn på frelse, at tilhøre de få udvalgte til et liv i det hinsides, der drev calvinisterne til en rationel livsførelse, hvor sparsommelighed, arbejdsomhed og et etisk kald var hovedingredienserne (Weber 1905-1905/1995). Døden er således indirekte til stede i Webers analyse i form af ønsket om frelse og udødelighed som drivkraft i puritanerens liv. Men for både Durkheim og Weber gjaldt det at de trods deres henvisninger til døden ikke interesserede sig i døden som sådan. De var derimod optaget af at forstå, forklare og beskrive det moderne samfunds fremvækst, dets muligheder og dets patologier. På den måde udgjorde døden ofte blot en forsvindende lille del af meget mere omfattende diagnoser og teorier om moderniteten. Døden i sig selv - de kulturelle opfattelser, forestillinger, praksisser og problemer, der knytter sig hertil - var ikke noget, de klassiske sociologer var optaget af.

En af de få der imidlertid interesserede sig mere systematisk og direkte med døden var den franske sociolog Robert Hertz, en elev af Durkheim der blev dræbt under Første Verdenskrig. Han tilhørte den såkaldte Année-skole der arbejdede ud fra det funktionalistiske perspektiv, som Durkheim havde grundlagt, og ligesom Durkheim betragtede Hertz også samfundet som et sammenhængende moralsk fællesskab, hvis værdier kom til udtryk gennem kollektive repræsentationer og manifestationer. Hertz var ganske vist optaget af religionssociologi, men han virkede også som antropolog med dybdegående og langvarig etnografisk indsamling af data i fremmede kulturer. Hertz' studier af Dayak-kulturen på Borneo fra starten af det 20. århundrede, der udkom samlet i $1960 \mathrm{i}$ bogen Death and the Right Hand, rummer to centrale essays om dødens repræsentation, begravelsespraksisser, overgangsriter og forestillinger om døden blandt disse primitive stammefolk, og særligt det første essay, "A Contribution to the Study of the Collective Representation of Death", citeres den dag i dag stadig hyppigt i såvel sociologisk som antropologisk litteratur. Hertz' hovedfortjeneste var at han viste at en forståelse 
af dødens kulturelle aspekter var vigtig - at det var gennem de kulturelle praksisser, der omgærder døden og særligt forholdet til den døde krop, at det sociale fællesskab opretholdes og genbekræftes. Også hans beskrivelse af de midlertidige begravelser [wet burials] af afdøde, der gik forud for den definitive begravelse [dry burials], var opsigtsvækkende (Hertz 1909/1960).

Udover disse klassiske studier, hvor døden ofte mest blev omtalt indirekte, udkom der også flere religions- eller professionsrelaterede bøger om amerikanske bedemænd, om dødsritualer og om udødelighedsforestillinger (jf. f.eks. Puckle 1926; Bendann 1930; Frazer 1913), men i det hele taget hørte det til sjældenhederne, at datidens sociologer og andre samfundsvidenskabsfolk interesserede sig indgående med døden. En forklaring kan være at det, der populært er kaldt dødstabuet, allerede på dette tidspunkt - både i samfund og i samfundsvidenskab - var særdeles fortættet, og døden blev formentlig heller ikke anset som et karrierefremmende eller lukrativt forskningstema i en disciplin, der i de første årtier var optaget af økonomi og politik.

\section{0-1970: Fundamentet lægges}

Det er nu mere end et halvt århundrede siden at de amerikanske sociologer William A. Faunce og Robert L. Fulton (1958) i en lille artikel efterlyste en mere vedvarende, indgående og systematisk sociologisk interesse i døden. De noterede sig at der fra sociologisk side havde været overraskende sparsom interesse for døden som forskningsfelt, mens eksempelvis antropologer og folkemindeforskere længe havde interesseret sig for primitive stammesamfunds ritualer og ceremonier ved dødsfald. Det der manglende var at blikket blev vendt indad mod det moderne vestlige samfund selv, dets institutioner og ritualer og de sociale implikationer af den død, der udspillede sig her. De konstaterede således, hvilket underbygger min tidligere påstand, hvordan "sociologer indtil for ganske nylig kun har udvist begrænset interesse for den sociologiske og socialpsykologiske betydning af døden« (Faunce \& Fulton 1958:205). Faunce og Fulton anså døden som et helt centralt element i det de betragtede som et 'kulturelt kompleks' af folkelige forestillinger, ritualer, professioner, ceremonier mv. - et kompleks der var essentielt for mere fyldestgørende at forstå en kultur eller et samfund i sin helhed. Dette opråb til sociologer om ikke at overse døden blev i årene efter hørt og besvaret fra forskellig side. På den ene side udkom der i denne periode en del strukturfunktionalistiske teorier om dødens og sorgens funktion i samfundet og på den anden side udkom der fænomenologiske teorier om dødens 
betydning for det enkelte menneske og dets relationer til andre. Disse teoretiske perspektiver tilbød vidt forskellige bud på og forståelser af dødens betydning for individ og samfundsliv, hvor strukturfunktionalismen fokuserede på samfundsplanet, mens fænomenologien fortrinsvis var optaget af individniveauet (Donaldson 1972:287-289).

Mange af de strukturfunktionalistiske teorier der blev udviklet om døden på dette tidspunkt, var forholdsvis forudsigelige, fordi de indskrev sig i den overordnede funktionalistiske ramme, der også blev anvendt til at forstå så forskelligartede fænomener som afvigelse, familie, ægteskab, social kontrol og selvmord. Et funktionalistisk perspektiv på samfundet betoner i almindelighed hvorledes handlinger og institutioner, som deres latente eller manifeste funktion, bidrager til opretholdelsen og vedligeholdelsen af samfundet som et samlet og integreret hele. Således også i forhold til døden, hvor den måde hvorpå døden håndteres, betragtes som funktionel for at samfundet kan fortsætte efter dets enkelte medlemmers $d ø d$, fordi døden ikke får mulighed for at forstyrre samfundets overordnede ligevægt. Faktisk mente strukturfunktionalisterne slet ikke at det moderne vestlige samfund, som det amerikanske, var underlagt dødsfortrængning, som mange andre ellers hævdede - det amerikanske værdisystem (det, Talcott Parsons kaldte 'instrumental aktivisme') sikrede derimod, at dødsfald ikke blev psykologisk lammende for befolkningen. To fremtrædende eksponenter skrev således: “Det amerikanske samfund har institutionaliseret en overvejende stabil, om end fleksibel og foranderlig, indstilling til døden, der grundlæggende ikke er 'fortrængning', men en slags accept, der er passende for vores primære kulturelle aktivitetsmønstre« (Parsons \& Lidz 1967:134). For strukturfunktionalisterne var dødsfortrængning således ikke et empirisk faktum i forhold til det amerikanske samfund, og de mente at man i det hele taget formåede at integrere døden i det overordnede værdisystem og de eksisterende institutioner. Inden for denne funktionalistiske tænkning udvikledes således forståelser der betoner hvordan samfundet som værdisystem formår at integrere døden, f.eks. i form af den såkaldte disengagement theory, der fremfører, at ældre og døende mennesker, grundet deres gradvise fysiske og mentale svækkelse og mindskede sociale funktion, både trækker sig ind i sig selv og samtidig af det omkringliggende samfund i stigende grad overlades til sig selv, og hvorledes en række institutioner - herunder f.eks. plejehjem - muliggør og understøtter denne naturlige og rolige afkoblingsproces fra det aktive samfundsliv så som den økonomiske sfære og det sociale fællesskab (Cummings \& Henry 1961). Alderdom og død forstyrrer således ikke den sociale orden. Derudover udkom der 
også funktionalistiske teorier om organdonation som en gensidigt forpligtende social relation (Parsons, Fox \& Lidz 1972), om den aftagende sociale værdi af ældre og døende og det hensigtsmæssige ved en bureaukratisering af døden (Blauner 1966), og i forhold til konstruktionen af og designet på bygninger og lokaliteter i samfundet, der skal tage vare på døden, så som kapeller og hospitaler, har funktionalistisk tænkning spillet kraftigt ind (Ragon 1983). Ligeledes anlagde W. Lloyd Warner (1959) i sin bog The Living and the Dead (og særlig i bogens tredje sektion) - der byggede på et årti-langt indgående studium af et lokalsamfund - et socialantropologisk, funktionalistisk perspektiv på, hvordan indbyggerne i den nordamerikanske by Newburyport (der i bogen kaldes Yankee City) forholder sig til døden og dødsfald i lokalsamfundet lige fra måden, man mindes de døde på med parader og på kirkegårde samt den symbolske betydning af dødsfald i forbindelse med krig til den fysiske indretning af kirkegårdene og afholdelsen af begravelsesceremonier. Warners hovedtese er som det i det hele er det for funktionalismens dødsfokus, at mennesker udfører kollektive ritualer og ceremonier for de afdøde for at kunne komme videre i livet og for at mindske den for samfundet forstyrrende frygt for døden, og at alle disse handlinger i sidste instans er med til at opretholde samfundets normative orden.

Den fænomenologiske tradition var på mange måder en direkte modreaktion på netop strukturfunktionalismens dominans i sociologien i midten af det 20. århundrede. Fænomenologerne mente at strukturfunktionalisterne overså den subjektive betydning, som handlinger og oplevelser har, og derved negligerede de den enkelte aktørs motiver og meningsdannelse. I forhold til døden var det særligt et religionssociologisk perspektiv fænomenologer som Peter L. Berger og Thomas Luckmann forfægtede. I deres optik udgør døden og den måde vi forholder os til den på, en social konstruktion, der er kulturelt og socialt betinget. Imidlertid erkender de at døden - i stort set alle samfund - udgør et brud i menneskers hverdagsliv, og religionen kan i den forbindelse tjene som en slags symbolsk univers, der igennem krisevedligeholdelse kan legitimere og forklare dødens tilstedeværelse og uundgåelighed som en del af hverdagslivet. Peter L. Berger skriver herom: "Eftersom intet samfund kan undgå visheden om døden, er legitimeringer af den sociale verdens virkelighed $i$ mødet med døden nødvendige for ethvert samfund. Religionens betydning i disse legitimeringer er åbenlys« (Berger 1969:52). Døden udgør ganske vist en dramatisk marginalsituation, en radikal trussel mod den virkelighed og institutionelle orden, som mennesker i deres hverdagsliv tager for givet. Berger og Luckmann skriver derfor om den rolle som symbolske universers legitimering af døden skal sikre: 
Alle legitimeringer af døden må udføre den samme væsentlige opgave - de må gøre individet i stand til at leve videre i samfundet, efter at signifikante andre er døde, og gøre det muligt at foregribe ens egen død med en i det mindste så lav grad af angst, at den fortsatte udførelse af hverdagens rutiner ikke paralyseres (Berger \& Luckmann 1966/1992:121).

Man kan måske argumentere for at der faktisk gemmer sig en vis pseudofunktionalisme i denne fænomenologiske måde at forstå døden på, hvor religion og trosforestillinger netop tjener det formål, den 'funktion', at sikre at samfundet kan fungere efter dødsfald, men det er netop betoningen af menneskers subjektive og intersubjektive møde med og oplevelse af døden snarere end af samfundets behov, der er det centrale for fænomenologerne. I dette perspektiv er det menneskers vedvarende forsøg på at skabe mening i et liv hvor døden indtræffer, der udgør omdrejningspunktet for såvel teoretisk udvikling som empirisk arbejde.

Hvor 1950'erne og de tidlige 1960'ere således var kendetegnet ved at døden gradvist, men stadig sporadisk, begyndte at vinde indpas inden for forskellige sociologiske traditioner og teoridannelser, kan man kalde perioden herefter for en slags stille revolution inden for thanatosociologien, hvor flere kritiske studier af hospitalsdøden i USA begyndte at sætte døden på den sociologiske og samfundsmæssige dagsorden. Mange af de bøger der blev skrevet på dette tidspunkt, vender sig mod den tendens, Geoffrey Gorer (1955) et årti tidligere havde karakteriseret som 'dødens pornografi', hvormed han henviste til, hvordan der i den vestlige verden var en morbid fascination af den unaturlige og dramatiske $\mathrm{d} \varnothing \mathrm{d}$, alt mens den naturlige $\mathrm{d} \varnothing \mathrm{d}$, som ramte langt de fleste mennesker, var omgærdet af en pinagtig tavshed og forlegenhed, som om døden var pornografisk og sorgen følelsesmæssig masturbation. Det der bredt er blevet betegnet Happy Death Movement, Natural Death Movement eller Death Awareness Movement, var i denne tid både en forløber for og en videreudvikling af den thanatosociologiske interesse for at skabe rammerne for en naturlig og værdig død (Doka 2003). På den måde var det også en tid hvor thanatosociologien i vid udstrækning anlagde et institutions- og samfundskritisk perspektiv. Dette var desuden tiden hvor særligt interaktionistiske studier af institutionelle kontekster som hospitaler og plejehjem dokumenterer, hvorledes det moderne samfund har vanskeligt ved at forholde sig til og håndtere døden, og hvordan den lægevidenskabelig-medicinske diskurs vanskeliggør det for den døende, de pårørende og de professionelle at udvikle en mere naturlig indstilling til døden og til det at miste. Særligt observationsstudier udført af David Sudnow (1967) og Barney G. Glaser og Anselm L. Strauss $(1965,1968)$ sætter fokus på den ofte kunstfærdige håndtering af og 
distance til døden på amerikanske hospitaler. For Sudnows vedkommende er det særligt differentieringen $\mathrm{i}$ behandlingen af patienter ud fra om de betragtes som 'værdifulde' at holde i live og forsøge at genoplive, hans fokus på hvordan dårlige nyheder bliver overbragt til de pårørende, håndteringen af den døde krop samt det han med et begreb fra Erving Goffman kaldte 'den sociale' død - at mennesker bliver betragtet som socialt døde, selvom de endnu fysisk er i live - der er resultatet af hans indgående hospitalsstudier. For Glaser og Strauss' vedkommende der med deres dødsstudier udvikler den såkaldte 'grounded theory'-tilgang, er det tilstedeværelsen af forskellige 'bevidsthedskontekster' - fra lukket via mistroisk og gensidigt foregivende til åben - og håndteringen af forskellige 'dødsforløb' - hurtige, langsomme, ventede og uventede - der udgør de væsentligste bidrag til denne tidlige thanatosociologi. ${ }^{4}$ Fælles for disse interaktionistiske studier er det at de bygger på direkte og længerevarende observation på hospitaler, hvorved de i modsætning til såvel de strukturfunktionalistiske og fænomenologiske teoridannelser afspejler nærkontant til en faktisk empirisk virkelighed.

Udover disse strukturfunktionalistiske, fænomenologiske og interaktionistiske teorier om og studier af død, sorg, institutionelle ritualer og praksisser samt kritikken af den unaturlige og fornægtende indstilling til døden i det moderne civiliserede samfund og dets institutioner udkommer der på denne tid også en del eksistentialistiske skønlitterære såvel som filosofiske værker om døden, hvor en identisk tematik udspiller sig - det enkelte menneskes uvindelige og ofte uværdige kamp mod døden som et eksistentielt grundvilkår og det absurde i den måde, samfundet forholder sig til døden på (Sartre 1965; de Beauvoir 1971). Ligeledes er det på denne tid at flere psykologiske og psykoanalytiske teorier om dødsangst og udødelighedsdrømme med umiskendeligt freudiansk islæt begynder at vinde indpas både i thanatosociologien og i mere populærvidenskabelige sammenhænge. Alt i alt kan perioden betragtes som en gradvis opvågning til erkendelsen af at døden også har en samfundsvidenskabelig berettigelse. Samtidig er denne periode kendetegnet ved at det diskuteres, hvorvidt samfundet er dødsfortrængende eller ej. Hvor særligt fortalere for en psykologisk eller psykoanalytisk indgangsvinkel til døden hævder at døden i det moderne samfund er fortrængt og bortgemt (f.eks. Feifel 1963; Kalish 1969), mener andre - fortrinsvis inden for den strukturfunktionalistiske tradition - at døden ikke udgør en trussel mod samfundets funktionsmåde. Diskussionen om de moderne vestlige samfund som dødsfortrængende forbliver efterfølgende uafklaret i en årrække fremover og diskuteres stadig (jf. Donaldson 1972; Kellehear 1984). 
Hvor særligt 1960'erne var et pionerende årti i forhold til at legitimere at døden kan og bør gøres til genstand for indgående sociologisk forskning, og hvor grundteoretiske positioner i forståelsen af døden som nævnt gradvist bliver fastlagt, tegnes fra midten af 1970'erne og frem konturerne af en decideret thanatosociologi (jf. Fulton 1977; Riley 1983), og siden da er der løbende udkommet en lind strøm af sociologiske introduktionsbøger til emnet, der gør det meningsfuldt at tale om udviklingen af en egentlig subdisciplin eller et felt (f.eks. Vernon 1970; Lofland 1976, 1978; Marshall 1980; Charmaz 1980; Elias 1983; Kearl 1989; Clark 1993; Seale 1998; Howarth 2007). Tilbage i starten af 1980'erne stiller David Unruh (1981) således spørgsmålet om der overhovedet findes en thanatosociologi. På daværende tidspunkt er svaret nok stadig et tøvende 'nej', men i løbet af få år kan dette udskiftes med et utvetydigt 'ja'. Det er dog ikke blot inden for sociologien at man i disse år oplever en opblomstring af interessen for døden som forskningstema. Psykologien gennemgår en periode med en genopdagelse af døden som Herman Feifel (1990) kalder det, hvis lige man skal årtier tilbage for at genfinde, så interessen for døden blomstrer på dette tidspunkt såvel inden for sociologi og psykologi og ligeledes også beslægtede discipliner. 1980'erne markerer inden for dødsforskningen måske mest af alt socialhistorikkens opdagelse af døden hvor der trækkes de lange linjer i dødens udviklingshistorie, hvor dokumentation for dødens historiske transformationer tilvejebringes, og hvor vingesuset fra de store fortællinger, som postmodernismen senere erklærede for døde, stadig varmede mange dødsforskeres bevidsthed (jf. f.eks. Ariès 1981; Richardson 1987; Vovelle 1983; Whaley 1981).

I denne forbindelse er det særligt Philippe Ariès - en fransk mentalitetshistoriker der både havde skrevet indgående om seksualitetens, privatlivets, familiens og barndommens forandring - der gjorde sig bemærket og satte et varigt fodaftryk på dødsforskningen, herunder også på thanatosociologien, med sine fantastiske værker - historisk detaljerede såvel som smukt illustrerede - om dødens historiske udvikling i den vestlige verden fra middelalderen op til anden halvdel af det 20. århundrede (Ariès 1974, 1981, 1983). Det var Ariès grundantagelse der senere blev kritiseret af bl.a. sociologer (f.eks. Elias 1983), at vores opfattelse af døden har udviklet sig fra en civiliseret og naturlig til en mere vild og deraf følgende kontrolfikseret indstilling. Han mener desuden at man analytisk kan inddele de seneste tusind års dødshistorie i Vesten i fire overordnede faser: den tæmmede død (middelalderdøden), selvets død (renæssancedøden), den andens død (romantikkens død) og den forbudte død (den moderne død). Denne udvikling bliver gradvist 
drevet frem af individualisering, sekularisering, ændrede familieforhold, demografiske forandringer og lægevidenskabens fremvækst, og som konsekvens heraf mener Ariès, at den moderne, forbudte og vilde død var en 'omvendt død' i forhold til den klassisk tæmmede død. Trods dens analytiske overskuelighed og historiske righoldighed har adskillige andre forskere imidlertid forholdt sig kritisk til flere aspekter af Ariès' imponerede faseteori, herunder karakteren af hans kildemateriale (hvor store dele af hans beskrivelser bygger på tvivlsomme eller sparsomme kilder), hans nostalgiske indstilling til den klassiske død og til hans relativt rigide faseopdeling. Flere har i de senere år desuden vendt sig mod Ariès' forbudte, bortgemte og tabubelagte død som en retvisende beskrivelse af nutidens dødsmentalitet. En anden fransk historiker, Michel Vovelle, konstaterede således det paradoksale i at man vedblev med at tale om eksistensen af et dødstabu, samtidig med at der som aldrig før blev skrevet og udgivet utallige bøger om døden: "Dødstabuet er den seneste mode, og alle tror, at han har opfundet det", og han fortsatte med at hævde, at "vi er blevet klar over dødstabuet i de moderne vestlige samfund ti til tyve år for sent« (Vovelle 1980:90). Flere forskere har siden hen påpeget at døden slet ikke længere er tabu eller fortrængt, og at vi i nutiden er vidner til en kraftig eksponering for døden også i det offentlige rum (jf. f.eks. Berridge 2002; Noys 2005). Et dansk islæt i denne socialhistoriske kortlægning af udviklingen af dødsopfattelser over flere århundreder er Ditlev Tamms (1992) Dødens triumf, der ligeledes trækker de store linjer op. På dansk grund har der i de senere år desuden været forsøg på at dokumentere og tegne konturerne af en ny femte dødsfase, den såkaldt 'spektakulære død', som en slags videreudvikling og udvidelse af den fasemodel, der naturligt afsluttedes med Ariès' egen død i midt-1980'erne. Der argumenteres for at vi befinder os i en 'mellemtid' mellem den moderne forbudte død på den ene side og en senmoderne eller postmoderne åbenhed over for døden på den anden (Jacobsen 2001, 2009).

Perioden 1970'erne til 1980'erne var også årtier hvor en lang række etiske problemstillinger aktualiserer døden både i samfundet og i samfundsvidenskaberne. Det var særligt i 1970'erne at problematikken om aktiv dødshjælp og kritikken af udsigtsløs livsforlængende behandling for alvor tog til, og hvor folkelige bevægelser satte døden på dagsordenen i forbindelse med retten til at dø og diskussionen om eutanasilovgivning f.eks. i USA. Sagen fra 1975 om Karen Ann Quinlan, der blev holdt kunstigt i live i komatøs tilstand i mere end ti år, var medvirkende til at rejse diskussioner om det etisk forsvarlige i den medicinske indgriben i menneskelivet, mens John Badhams filmatisering fra 1978 af Brian Clarks kontroversielle bog fra 1972 Whose Life Is It Anyway, der fik meget offentlig bevågenhed, blot 
var et par af milepælene i problematikken omkring aktiv dødshjælp. Samtidig begynder cancerproblematikken og erkendelsen af at en løsning herpå lå langt ude i fremtiden, at øge bevidstheden om nødvendigheden af at skabe institutionelle rammer, der ikke længere fornægter døden. Desuden kommer 1980'erne til at stå i AIDS-sygdommens tegn, hvor de mange dødsfald og de medfølgende ofte følelsesladede politiske diskussioner om død, skam, synd og seksualitet bevirker, at den seksuelt relaterede død - ikke kun blandt homoseksuelle - ikke længere kan holdes hemmelig. Så mens seksualiteten grundet AIDS-epidemien således er på vej tilbage i skabet efter et par årtier med hidtil uset frisættelse, er døden, kort sagt, først i disse år på vej ud af skabet. Det er ligeledes i denne periode, denne brydningstid for døden, at hospice-bevægelsen gradvist begynder at vinde frem fortrinsvis i Storbritannien og USA. Foranlediget af bl.a. Cicely Saunders, der i 1967 grundlagde det første hospice, Sct. Christopher's i London, bliver hospicetanken adopteret mange andre steder, og det sætter sig dybe spor i forhold til udviklingen af en palliativ videnskab og praksis om omsorg for og pleje af terminalt syge og døende (Saunders et al. 1981). I midten af 1970'erne åbnes det første hospice i USA, The Connecticut Hospice, og hurtigt herefter etableres hospices for terminalpatienter rundt omkring i Vesteuropa. ${ }^{5}$ Samtidig hermed udgiver Elisabeth Kübler-Ross (1969) den banebrydende bog Om døden og den døende, der bl.a. omhandler det moderne samfunds manglende anerkendelse af døden, som kritiserer den lægevidenskabelige tilgang til døden og som præsenterer den berømte fasemodel over sorgfaser, der siden har været dagsordensættende. Desuden udkommer der flere psykologiske og psykoanalytiske bøger om dødsfornægtelse og fortrængning, der også når uden for snævre akademiske kredse (Becker 1973; Brown 1959/1985). Fokus i denne periode er således ikke kun på en værdig død (Death With Dignity-tankegangen), men også på en naturlig død, og mange af de etiske, juridiske og institutionelle problemstillinger, der i disse årtier bliver rejst, bevirker, at man ønsker stadig mere viden om forholdet til døden og den måde mennesker, institutioner og samfund forholder sig til livsafslutningen på. Thanatosociologien begynder således gradvist at vise sin berettigelse.

\section{0-1990: Den palliative revolution}

Hvor det siden slutningen af 1950'erne således gradvist begyndte at være oplagt for sociologer at forholde sig til og beskæftige sig med døden, er det dog først et par årtier senere at en decideret thanatosociologi etableres. ${ }^{6}$ Hvornår en subdisciplin kan siges at være etableret er naturligvis ikke noget, der findes faste eller 
formelle retningslinjer for, men fra slutningen af 1970'erne og frem sker der gradvist det, at specialiserede fagtidsskrifter inden for thanatosociologien som Omega: Journal of Death and Dying, Death Studies, Death Education og senere Mortality bliver grundlagt. Derudover begynder artikler om døden at blive publiceret også uden for disse fagspecifikke tidsskrifter, om end det dog stadig hører til sjældenhederne. Samtidig udgives der, som nævnt ovenfor, et stigende antal grund- og undervisningsbøger inden for feltet fortrinsvis rettet mod sygeplejersker, men også mod sociologer, der har en interesse i døden. Der afholdes seminarer og konferencer og gradvist opbygges der nationale og internationale netværk af forskere, der fra et samfundsvidenskabeligt perspektiv er optaget af at forstå og fortolke døden i det moderne samfund.

Kimene til thanatosociologien som sociologisk subdisciplin sås i disse år særligt i Storbritannien hvor det tidligere i 1960'erne var i USA, at interessen var størst. En af forklaringerne herpå lyder at der på daværende tidspunkt var en markant arbejdsløshed blandt britiske sociologer, hvorfor man så sit snit til at skabe sig en ny niche - døden - der kunne sikre fremtidig ansættelse og karriere (Walter 1993). Jeg tror dog at andre forklaringer er mere oplagte. For det første spiller nogle af de føromtalte nye udfordringer for samfundet $i$ almindelighed og for sundhedsprofessionelle, patienter og pårørende i særdeleshed i forbindelse med cancer, AIDS og diskussionen om aktiv dødshjælp ind. Samtidig har problemer forbundet med den hastigt voksende andel af ældre i samfundet, som velfærdsstaten skal tage vare på, også medført øget fokusering på de sociale aspekter af døden. Desuden har den såkaldt 'ekspressive revolution' i 1960'erne og 1970'erne, der satte eksistentielle og følelsesmæssige spørgsmål på dagsordenen efter årtiers fravær, også aktualiseret mere humanistiske aspekter af døden. En sidste vigtig katalysator i denne udvikling af thanatosociologien som er relateret til disse nye samfundsvilkår, er utvivlsomt ekspansionen hvis ikke ligefrem revolutionen inden for det palliative felt, som omtalt ovenfor, hvor det bliver stadig mere påkrævet, at stadig flere faggrupper inden for sundhedsvæsenet er i stand til at håndtere kontakten til terminalpatienter, der nu i modsætning til tidligere lever længere med døden.

\section{0-2000: Mellem faglighed og tværfaglighed}

Hvor de foregående årtier på mange måder udviser en langsom men sikker progression hen mod en anerkendelse af døden som sociologisk relevant forskningstema, er 1990'erne et årti med institutionaliseringen af hospices og palliativ praksis 
mange steder og med en indholds- og omfangsmæssigt ekspansion inden for det samfundsvidenskabelige studium af døden. Dette årti bliver således, både dansk og internationalt, et vigtigt årti for dødsforskningen og for interessen for det palliative felt. Særligt i Storbritannien er thanatosociologien i vækst, og David Clarks (1993) antologi The Sociology of Death udgør på mange måder en slags startskud til en veritabel bølge af litteratur om døden, der senere bliver fulgt op af adskillige andre antologier, hvor feltets linjer trækkes op, og hvor forskningsdagsordner bliver fastlagt (Howarth \& Jupp 1996; Jupp \& Howarth 1997). Nogle af pionererne i denne nye interesse for thanatosociologi er Glennys Howarth, Peter C. Jupp og Tony Walter, der såvel empirisk som teoretisk markerer feltet. Samtidig udkommer en række bøger, der på baggrund af dybdegående empirisk arbejde beskriver det praktiske og symbolske arbejde, der bl.a. udføres i lighuse, blandt bedemænd og retsmedicinere (Prior 1989; Howarth 1996; Bradbury 1999), der tydeliggør behovet for viden på områder, der hidtil har været forskningsmæssigt underbelyst. Samtidig markerer flere af de fremtrædende sociologiske skikkelser sig med bøger der specifikt omhandler eller berører døden (f.eks. Bauman 1992; Baudrillard 1993; Giddens 1996), hvilket øger fokus på døden endnu mere. Der bliver med hyppige mellemrum afholdt konferencer og seminarer hvor thanatosociologer mødes og præsenterer deres teorier og studier, og på flere engelske universiteter bliver kurser eller moduler i The Sociology of Death and Dying udbudt. Tony Walter (2008:329) har for nylig udtrykt bekymring for, at ligesom interessen for thanatosociologi langsomt stagnerede i USA efter opblomstringsårene i 1960'erne, er der i disse år tegn på, at subdisciplinen måske skal opleve samme skæbne i Storbritannien efter sin ekspansive vækst netop i 1990'erne. Meget tyder imidlertid på at thanatosociologien efter at være trådt ind i et nyt årtusinde stadig tiltrækker sig forskningsmæssig interesse, også i Storbritannien.

I Danmark - som i resten af Skandinavien - er 1990'erne om end i mindre målestoksforhold, også skelsættende for det palliative felt i almindelighed og thanatosociologien i særdeleshed. I det hele taget er perioden op mod og umiddelbart efter årtusindeskiftet kendetegnet ved en kraftigt stigende politisk og folkelig opmærksomhed mod døden herhjemme med Kræftplan I og II, hospiceetableringer og den medfølgende formning af en palliativ fagidentitet (jf. Vejlgaard, Sjøgren \& Maagaard 2007; Raunkiær 2008). Centralt for formningen af den palliativ fagidentitet er særligt bøger af Marianne Davidsen-Nielsen (1995) og Davidsen-Nielsen \& Nini Leick 1987/1991), der er medvirkede til på indlevende måde at sætte mødet med døden, de pårørendes sorg, det menneskelige tab samt trøst og håb på det palliative landkort herhjemme. Ligeledes udgør den 
tværfaglige og velbesøgte konference ‘Dødens Rum' på Hollufgaard ved Odense Universitetscenter i 1997 et markant vitaliseringsmoment for dødsforskningen i Danmark. Her møder forfattere, teologer, sociologer, psykologer, socialrådgivere, sygeplejersker præster, landskabsarkitekter og en lang række faggrupper hinanden og diskuterer døden, hvilket resulterede i en stadig anbefalelsesværdig tværfaglig udgivelse (Petersen \& Sommer 1998). Næsten samtidig bliver thanatosociologien for første gang eksplicit italesat i det danske sociologimiljø (Jacobsen 1998). I det hele taget er 1990'erne en periode hvor det langsomt men sikkert bliver både fagligt legitimt og karrieremæssigt meningsfuldt at interessere sig for døden i sociologien, og det er også noget der afspejles i mediernes stigende interesse for og bevågenhed mod at belyse de områder af samfundslivet, hvor døden er til stede.

\section{0 og frem: Fra nutid til fremtid}

Som det er vist ovenfor, lever thanatosociologien i disse år, dansk som internationalt, i bedste velgående - faktisk bedre end nogensinde før. Glennys Howarth indleder således sin nye introduktionsbog til thanatosociologien med betragtningen: "Det forekommer som om, at vi i de vestlige samfund gennemlever en periode, hvor studiet af døden og erkendelsen af menneskets dødelighed vinder frem « (Howarth 2007:19). I Danmark er det dog først inden for de seneste 10-15 år, at interessen for thanatosociologi og beslægtede fagområder for alvor har taget fart. Som nævnt har det palliative felt siden starten af 1990'erne kontinuerligt været i vækst, bl.a. foranlediget af oprettelsen og den gradvise institutionalisering af hospices og en tiltagende faglig organisering og opkvalificering af det palliative felt. Således er der i de senere år oprettet videnscentre, forskningsgrupper og netværksdannelser inden for den palliative indsats. På uddannelsesfronten følges trop, og flere steder - eksempelvis i Schweiz og Spanien - har man i efterhånden flere år haft masteruddannelser inden for thanatologi, og på University of Bath i Storbritannien findes der et decideret Centre for Death and Society. I Danmark udbydes der fra foråret 2010 på Aalborg Universitet en masteruddannelse i ‘humanistisk palliation' hvor netop thanatosociologien står centralt. Uddannelsen er bredt rettet mod praktikere inden for en lang række fagfelter der ønsker at forske i egen praksis, og der undervises således i fagmoduler som sociologi, psykologi, palliation, gerontologi, teologi, etik og filosofi mv. med henblik på at tilbyde praktikere inden for det palliative felt en faglig opkvalificering af praksis samt specialiseringsmuligheder inden for studiet af dødens mere sociale aspekter. 
Masteruddannelsen bygger desuden på et ønske om at der på det palliative uddannelsesområdet sker en udvikling i retning af en kombination af forskningsbaseret undervisning og undervisningsbaseret forskning, hvorved forskning og praksis gensidigt kan berige hinanden (Jacobsen 2008). Også andre steder på universiteter og på de nye university colleges udbydes der uddannelsesmæssige tiltag, hvor særlige moduler målrettes det palliative felt. Thanatosociologien bliver således i stigende grad tilgængelig for praktikere der har deres daglige virke ude i dødens virkelighed på hospitaler, hospices, plejehjem, i regioner og kommuner eller inden for forsknings- og uddannelsessektoren, og som gennem disse tiltag tilbydes mulighed for tværfaglig inspiration og faglig specialisering. Med denne uddannelsesmæssige oprustning sikres samtidig fremtidig rekruttering inden for det palliative felt.

Ikke blot på den uddannelsesmæssige front, men også i forskningsmæssig sammenhæng opleves i disse år en intensiveret interesse for døden. På dansk grund har flere studier i de senere år således trukket på indsigter fra thanatosociologien i udgivelser om børn og døden (Løw 2006), i forbindelse med diskussioner om den etiske og værdige død (Brock \& Samsø 2005), i udviklingen af dødssociologien som en sociologi om 'det unævnelige' (Jacobsen 2001), i kortlægningen af dansk begravelseskultur (Jensen 2002; Sommer 2003; Kragh 2004), i forbindelse med hjemmedød og plejeorlov (Dalgaard 2004), og i relation til en lang række temaer så som døden på plejehjem, alderdom, ensomhed og død, dødsfotografier, kirkegårdsudsmykning, døden i dansk børnebogslitteratur, døden på internettet, oplevelsen af terminal sygdom, udstillingen af døde kroppe, håndteringen af døden i lighuse, forandringen over tid i nekrologer og dødsannoncer, nye etniske begravelsesritualer og dødsopfattelser i fremmede kulturer (jf. Jacobsen \& Haakonsen 2008) for blot at nævne nogle af de få områder hvor thanatosociologiske perspektiver til stadighed anvendes og udvikles. ${ }^{7}$ Thanatosociologien er derfor heller ikke længere udelukkende et angloamerikansk fænomen. I mange europæiske lande forskes der nu med sociologisk optik i døden, og i Tyskland er der således i de senere år opstået en omsiggribende interesse for thanatosociologi (jf. f.eks. Feldmann 1997; Knoblauch \& Zingerle 2005; Schneider 2006), mens også sydeuropæiske og østeuropæiske samfundsforskere efterhånden har taget døden til sig. Thanatosociologien oplever således i disse år medvind i sejlene, men det er vigtigt at sikre, at den ikke stagnerer eller sejrer sig ihjel. Derfor er de visse udfordringer for den thanatosociologiske subdisciplin som må adresseres og afklares for at sikre fortsat faglig udvikling og samfundsmæssig anvendelse og relevans af den viden, der genereres. 


\section{Thanatosociologiske udfordringer}

Døden er kommet for at blive - det er derfor min forhåbning og forventning at thanatosociologien også er det, netop fordi den kan bistå os med til at forstå døden og ikke mindst livet forud for og i forbindelse med døden på en mere fyldestgørende og kvalificeret måde. Som jeg har beskrevet i det foregående har thanatosociologien - som en del af sociologiens generelle udbredelse og fremvækst og som såvel katalysator for som konsekvens af dødens genkomst i samfundet - i løbet af de seneste halvtreds år gennemgået en gradvis udviklings- og modningsproces, der i de seneste årtier, dansk som internationalt, har medført en konsolidering og kvalificering af feltet. Dette er efter min opfattelse en positiv tendens, men der lurer også nye udfordringer forude. Afslutningsvis vil jeg således kort berøre seks udfordringer, som thanatosociologien må forholde sig til fremover, hvis dens fremtidige eksistensberettigelse, udvikling og ekspansion skal sikres.

For det første det normative-kritiske aspekt. Som jeg var inde på indledningsvis, kan thanatosociologien ikke alene defineres som videnskab ud fra dens kritiske eller moralske potentialer, men udelukkende ud fra karakteren af den viden, der tilvejebringes. Det er derfor vigtigt at thanatosociologien fortrinsvis forholder sig beskrivende og analyserende til sit genstandsfelt, døden, og ikke blot forfalder til en kritisk kommentering på nutidig praksis. Der har været en vis tilbøjelighed til at det normative-kritiske aspekt har været fremherskende i mange thanatosociologiske studier, måske fordi thanatosociologien befinder sig i et spændingsfelt mellem praksis og akademisk disciplin, hvor erfaringer med uhensigtsmæssig håndtering af døden fra praksisfeltet ofte har været dagsordensættende. Denne forening af abstrakte teorier om f.eks. dødsangst, fortrængning eller sorgfaser med konkrete empiriske studier fra daglig praksis, denne integration af teori og praksis, er både prisværdig og pionerende, men thanatosociologien må overlade det normative-kritiske aspekt til andre faggrupper og i videst muligt omfang fokusere på at studere og afdække vores forhold til og håndtering af døden som et udtryk for en given samfundsmæssig eller kulturel praksis, uanset karakteren heraf.

For det andet det substantielle aspekt. Thanatosociologi beskæftiger sig som nævnt med de sociale og kulturelle dimensioner af døden, uanset karakteren heraf. Tony Walter mener dog at "størstedelen af dødens sociologi er interesseret i almindelige menneskers almindelige dødsfald« (Walter 2008:325). Dette er i og for sig rigtigt, netop fordi der derved afdækkes mere omsiggribende og generelle sociale forhold omkring døden, der gælder for mange forskellige mennesker, men 
thanatosociologien må naturligvis også forholde sig til de dødsfald samt deres sociale og symbolske implikationer, der ikke er mainstream, og som dermed afviger fra normen. Oplevelsen af døden er nemlig ikke den samme for alle. Derfor har der særligt i de senere år været en stigende interesse for at forske i dramatiske dødsfald og deres sociale og symbolske implikationer i såvel historiske som mere hverdagslige kontekster. Eksempler herpå er studier af den kollektive sorg og de minderitualer der fulgte i kølvandet på Prinsesse Dianas dramatiske død i 1997 (Kear \& Steinberg 1999; Walter 1999), men der har også været en stigende forskningsmæssig interesse for de såkaldte 'spontanaltre' (samlinger af blomster, fyrfadslys og andre personlige genstande), der fra tid til anden på gader og stræder markerer, at her er et almindeligt menneskeliv tabt som følge af trafikulykker eller voldelige overfald (Jacobsen 2007; Haney, Leimer \& Lowery 1997). På den måde interesserer thanatosociologien sig såvel for de 'almindelige' dødsfald som for de ekstraordinære og dramatiske dødsfald, der bryder med almindelig praksis. Jeg tror desuden at vi i de kommende år vil se, at thanatosociologer bliver stadig mere optagede af det exceptionelle og særprægede end af den ordinære og naturlige død. Det gælder imidlertid om at finde en balancegang herimellem.

For det tredje det kvalitative aspekt. Tony Walter konstaterede for nylig hvordan "sociologisk forskning i døden i vid udstrækning har været kvalitativt orienteret« (Walter 2008:323). Dette gælder ikke kun for den internationale forskning, men måske i særlig grad for dansk forskning, hvor de fleste undersøgelser inden for feltet anvender en kvalitativ metodisk tilgang. De få statistiske undersøgelser jeg har kendskab til af kvantitativ karakter, er derfor udarbejdet af analysebureauer som Vilstrup eller Gallup og er ikke synderligt strukturerede eller sociologiske. Der er intet i vejen med at foretrække at anvende kvalitative metoder som interviews eller observation når man studerer døden, netop fordi man derved ofte opnår en mere nuanceret viden og dybdegående forståelse. Men der skal lyde en opfordring til at der fremover også satses på at indsamle viden om døden i Danmark af mere kvantitativ karakter, således at danskernes nuancerede, forskelligartede og foranderlige, men også kulturelt særegne og nationalt karakteristiske forhold til døden afdækkes og dokumenteres. Der er derfor vigtigt at det kvantitative perspektiv opdyrkes mere. En af grundene til dets fravær skyldes formentlig at meget dødsforskning foregår i regi af sygeplejeuddannelser, hvor vægtlægningen af kvantitativ metode og statistik traditionelt ikke står så stærkt som kvalitative metoder. Såfremt vi skal vide mere om meget mere omfattende populationer - som f.eks. danskerne og døden - må vi nødvendigvis sikre, at den kvantitative del af thanatosociologien fremadrettet udvikles. 
For det fjerde det komparative aspekt. Tony Walter (2008) efterlyser mere komparativ sociologisk forskning i døden - på tværs af tid og rum. Dette er jeg enig i. Vi kommer meget bedre og mere fyldestgørende til at forstå vores egen dødskultur og få indblik i og tage ved lære af andres ved at foretage komparative undersøgelser af, hvordan andre kulturer eller historiske tidsperioder har forholdt sig til døden. Komparative studier sætter ens samtid i relief, og derfor er det ikke bare den tidligere omtalte socialhistoriske tradition, som ser på forandringer i dødsopfattelser i det lange historiske perspektiv, der skal styrkes, men også en synkron tilgang, hvorved forskelle og ligheder mellem nutidigt sameksisterende dødskulturer bliver afdækket.

For det femte det teoretisk-empiriske aspekt. Tidligere var jeg inde på rummeligheden af thanatosociologien som et tegn på dens faglige modenhed og styrke. Til trods for en omfattende rummelighed er der dog til stadighed visse teoretiske mangler i thanatosociologien, dansk som international. For det første er mange af de perspektiver der anvendes, enten udelukkende teoretisk eller empirisk forankrede, mens kombinationen af eksisterende teori og nyt empirisk materiale forekommer relativt fraværende, lige såvel som motivationen for udvikling af ny teori kan styrkes. For det andet mangler der, som Tony Walter (2008:322) bemærker, en generel interesse for teoretiske konfliktperspektiver som f.eks. marxisme. Derved mistes måske et vigtigt blik for de sider af døden i vores samfund, der omhandler social stratifikation, fremmedgørelse eller andre mere konfliktrelaterede forhold.

Slutteligt det disciplinære aspekt. Hvordan skal thanatosociologien sikres fremover? Her er det vigtigt, at den 'faste garde' - dansk som international - løbende suppleres og fornys med nye og yngre energiske kræfter. Det værste, der kan overgå såvel videnskabelige discipliner som subdiscipliner er, at de bliver sekterisk-lukkede, selvreferentielle eller fagligt selvsupplerende, hvorved den faglige udvikling og nytænkning stagnerer. Derfor er det vigtigt at der ikke blot forskningsmæssig men også uddannelsesmæssigt vedvarende foregår en udvikling faglig og tværfaglig - af thanatosociologien.

Det er min opfattelse at såfremt thanatosociologien formår at forholde sig til disse seks udfordringer i forhold til den nuværende praksis og status på feltet, så går den en glorværdig fremtid i møde, der måske kan råde bod på mange årtiers fravær. 


\section{Noter}

1: I bogen Det uhyggelige citerer Sigmund Freud således den tyske romantiske forfatter Friedrich Schelling for definitionen på det uhyggelige: “Uhyggeligt er alt det, der burde være forblevet hemmeligt, skjult, men som er trådt frem« (Freud 1919/1998:23). Fra midten af det 20. århundrede og fremefter, som denne artikel senere vil illustrere, bliver døden arketypen på det uhyggelige - det, der træder frem, trods ihærdige forsøg på at holde det skjult og hemmeligt.

2: Betegnelsen 'thanatosociologi' er foretrukket her af flere årsager. For det første fordi det er en betegnelse, der - selvom den stadig ikke er voldsomt udbredt - vinder stadig mere frem i det internationale fagmiljø, for det andet for at være med til at søsætte en gældende dansk betegnelse for feltet og for det tredje fordi denne betegnelse - alt andet lige - både forekommer mindre morbid og mere 'videnskabelig' og mundret end eksempelvis betegnelser som 'dødssociologi', 'dødens sociologi' eller 'sociologien om døden og de døende'. Indholdsmæssigt dækker de dog over det samme felt - studiet af døden som socialt og kulturelt fænomen.

3: Diskussionen om deskriptiv versus normativ sociologi, om 'er' overfor 'bør', er en klassisk problemstilling, og ligesom der ikke findes et entydigt svar for sociologien i almindelighed, findes der det heller ikke for thanatosociologien. Hvor visse thanatosociologer er særdeles normative, er andre mere deskriptive. Men som definition på en videnskab om døden er det i udgangspunktet ikke thanatosociologiens opgave at kommentere på rigtigheden eller ønskværdigheden af bestemte dødsopfattelser, dødshåndteringer eller dødsforestillinger - den skal derimod dokumentere, at de eksisterer, og analysere på den betydning de har for mennesker, institutioner og samfund.

4: I starten var det fortrinsvis den død, der udspillede sig på hospitaler, og som var underlagt en medicinsk rationalistisk diskurs, det sociologiske søgelys blev rettet mod. Senere er det dog også plejehjemsdøden, som stadig flere ældre i den vestlige verden oplever op igennem anden halvdel af det 20. århundrede, der skaber grobund for kritiske studier. En af det mest omtalte bøger fra denne tid er Robert Jay Baums (1977) sønderlemmende kritik i Warehouses for Death af plejehjem som 'dødens opbevaringssteder', hvor de ældre bliver socialt isoleret i institutionelle strukturer og rammer, der ikke muliggør en menneskeværdig eller meningsfuld afsked med livet.

5: Det første hospice i Danmark, Sankt Lukas Hospice i Hellerup, åbnede i 1992. I skrivende stund er der 15 hospices i Danmark, med flere nye under etablering, samtidig med at der findes palliative afdelinger på flere danske sygehuse.

6: Den thanatosociologiske subdisciplin trækker selv såvel empirisk som teoretisk på en række andre sociologiske subdiscipliner så som kropssociologi, religionssociologi, medicinsk sociologi, aldringssociologi, organisationssociologi, barndomssociologi og følelsessociologi. Ligeledes trækkes på mere generelle sociologiske teorier om modernitet, senmodernitet, postmodernitet, individualisering, identitet osv.

7: En nyttig oversigtstekst over de senere års udvikling inden for den danske samfundsvidenskabeligt-orienterede dødsforskning i almindelighed og livsafslutningspsykologien i særdeleshed findes i Agger (2008). En god oversigtsartikel til undervisning i thanatologiske temaer er Morgan (1999), selvom den ikke længere er opdateret med de nyeste perspektiver. 


\section{Litteraturliste}

Agger, N.P. (2008). "Dødsnavigering - psykologiens bidrag til den postmoderne død", i Michael Hviid Jacobsen \& Mette Haakonsen (red.): Memento mori - døden $i$ Danmark $i$ tvxrfagligt lys. Odense: Syddansk Universitetsforlag.

Ariès, P. (1974). Western Attitudes Toward Death from the Middle Ages to the Present. Baltimore: Johns Hopkins University Press.

Ariès, P. (1981). The Hour of Our Death. London: Allen Lane.

Ariès, P. (1983). Images de l'homme devant la mort. Paris: Seuil.

Baudrillard, J. (1993). Symbolic Exchange and Death. London: Sage Publications.

Baum, D.J. (1977). Warehouses for Death: The Nursing Home Industry. Don Mills, OH: Burns \& MacEachern.

Bauman, Z. (1992). Mortality, Immortality and Other Life Strategies. Cambridge: Polity Press. Bendann, E. (1930). Death Customs. London: Kegan Paul.

Beauvoir, S. de (1971). En skånsom død. København: Vintens Forlag.

Becker, E. (1973). The Denial of Death. New York: Free Press.

Berger, P.L. (1969). The Social Reality of Religion. London: Faber.

Berger, P.L. \& T. Luckmann (1966/1992). Den samfundsskabte virkelighed. København: Lindhardt \& Ringhof.

Berridge, K. (2002). Vigor Mortis: The End of the Death Taboo. London: Profile Books.

Blauner, R. (1966). “Death and Social Structure«. Psychiatry, 21:378-394.

Bradbury, M. (1999). Representations of Death: A Social Psychological Perspective. London: Routledge.

Brock, S. \& A. Samsø (red.)(2005). Mens vi venter på døden - døden i etisk og kulturfilosofisk belysning. Århus: Philosophia.

Brown, N.O. (1959/1985). Life Against Death: On the Psychoanalytic Meaning of History. Middletown, CT: Wesleyan University Press.

Charmaz, K.C. (1980). The Social Reality of Death. Reading, MA: Addison-Wesley.

Clark, D. (red.)(1993). The Sociology of Death: Theory, Culture, Practice. Padstow: Blackwell.

Cumming, E. \& William E.H. (1961). Growing Old: The Process of Disengagement. New York: Basic Books.

Dalgaard, K.M. (2004). Når familien træder til. København: Hans Reitzels Forlag.

Davidsen-Nielsen, M. (1995). Blandt løver. København: Munksgaard.

Davidsen-Nielsen, M. \& Nini L. (1987/1991). Den nødvendige smerte. København: Munksgaard.

Doka, K.J. (2003). "The Death Awareness Movement: Description, History and Analysis", i Clifton D. Bryant (red.): Handbook of Death \& Dying, Volume 1: The Presence of Death. Thousand Oaks, CA: Sage Publications.

Donaldson, P.J. (1972). “Denying Death: A Note Regarding Some Ambiguities in the Current Discussion«. Omega: Journal of Death and Dying, 3 (4):285-290.

Durkheim, É.(1897/1951). Suicide. New York: Free Press.

Durkheim, É. (1915). The Elementary Forms of Religious Life. London: Unwin.

Elias, N. (1983). De døendes ensomhed. København: Tiderne Skifter.

Faunce, W.A. \& Robert L.F. (1958). “The Sociology of Death: A Neglected Area of Research«. Social Forces, 36 (3):205-209.

Feifel, H.(1963). “Death”, i Norman Farberow (red.): Taboo Topics. New York: Atherton Press. 
Feifel, H.(1990). “Death and Psychology: Meaningful Rediscovery«. American Psychologist, 45:537-543.

Feldmann, K. (1997). Sterben und Tod: Sozialwissenschaftliche Theorien und Forschungsergebnisse. Opladen: Leske + Budrich

Frazer, J.G. (1913). The Belief in Immortality and the Worship of the Dead. London: Macmillan.

Freud, S. (1919/1998). Det uhyggelige. København: Politisk Revy.

Fulton, R.L. (1977). “The Sociology of Death«. Death Education, 1 (1):15-25.

Giddens, A. (1996). Modernitet og selvidentitet - selvet og samfundet under sen-moderniteten. København: Hans Reitzels Forlag.

Glaser, B.G. \& Anselm L.S. (1965). Awareness of Dying. Chicago: Aldine.

Glaser, B.G. \& Anselm L.S. (1968). Time for Dying. Chicago: Aldine.

Gorer, G. (1955). “The Pornography of Death«. Encounter, oktober:49-52.

Haney, A., C. Leimer \& J. Lowery (1997). “Spontaneous Memorialization: Violent Death and Emerging Mourning Ritual«. Omega: Journal of Death and Dying, 35 (2):159-171.

Hertz, R. (1909/1960). Death and the Right Hand. Glencoe, IL: Free Press.

Howarth, G. (1996). Last Rites: The Work of the Modern Funeral Director. New York: Baywood Publishing Company.

Howarth, G. (2007). Death and Dying: A Sociological Introduction. Cambridge: Polity Press.

Howarth, G. \& Peter C.J. (red.)(1996). Contemporary Issues in the Sociology of Death, Dying and Disposal. London: Macmillan.

Jacobsen, M.H. (1998). “Dødens sociologi - seneste skud på den sociologiske grundstamme?«. Dansk Sociologi, 9 (4):67-86.

Jacobsen, M.H. (2001). Dødens mosaik - en sociologi om det unæonelige. København: Gyldendal.

Jacobsen, M.H. (2007). “Den spontane sorgs ritualer«. Omsorg: Nordisk tidsskrift for palliativ medisin, 24 (1):7-22.

Jacobsen, M.H. (2008). Humanistisk palliation - mellem uddannelse og forskning. Upubliceret manuskript i forbindelse med akkreditering og udvikling af masteruddannelse, Institut for Sociologi, Socialt Arbejde \& Organisation, Aalborg Universitet.

Jacobsen, M.H. (2009). Døden - essays fra et årti. Odense: Syddansk Universitetsforlag.

Jacobsen, M.H. \& M. Haakonsen (red.)(2008). Memento mori - døden i Danmark i tværfagligt lys. Odense: Syddansk Universitetsforlag.

Jensen, J.F. (2002). Vest for paradis: Begravelsespladsernes natur. København: Gyldendal.

Jupp, P.C. \& G. Howarth (red.)(1997). The Changing Face of Death: Historical Accounts of Death and Disposal. London: Routledge.

Kalish, R.A. (1969). "The Effects of Death Upon the Family”, i Leonard Pearson (red.): Death and Dying. Cleveland, $\mathrm{OH}$ : The Press of Case Western Reserve University.

Kear, A. \& D.L. Steinberg (red.)(1999). Mourning Diana. London: Routledge.

Kearl, M.C. (1989). Endings: A Sociology of Death and Dying. New York: Oxford University Press.

Kellehear, A. (1984). “Are We a 'Death-Denying' Society? - A Sociological Review«. Social Science and Medicine, 18 (9):713-723.

Kellehear, A. (2007). A Social History of Dying. Cambridge: Cambridge University Press.

Knoblauch, H. \& A. Zingerle (2005). Thanatosoziologie: Tod, Hospiz und die Institutionalisierung des Sterbens. Berlin: Duncker \& Humblot. 
Kragh, B. (2004). Til jord skal du blive ... Dødens og begravelsens kulturhistorie i Danmark 17801990. Sønderborg/Aabenraa: Sønderjyllands Amt/Aabenraa Museum.

Kübler-Ross, E. (1969). Døden og den døende. København: Gyldendal.

Lepenies, W. (1988). Between Literature and Science: The Rise of Sociology. Cambridge: Cambridge University Press.

Lofland, L.H. (red.)(1976). Toward a Sociology of Death and Dying. Beverly Hills, CA: Sage Publications.

Lofland, L.H. (1978). The Craft of Dying: The Modern Face of Death. Beverly Hills, CA: Sage Publications.

Løw, J. (red.)(2006). Kender du et barn som har mistet? København: Mellemgaard.

Marshall, V.W. (1980). Last Chapters: A Sociology of Aging and Dying. Monterey, CA: BrooksCole.

Mellor, P. \& C. Shilling (1993). "Modernity, Self-Identity and the Sequestration of Death «. Sociology, 27 (3):411-431.

Morgan, J.D. (1999). “Basic Resources in Death and Bereavement«. International Journal of Group Tensions, 28 (1-2):25-35.

Noys, B. (2005). The Culture of Death. Oxford: Berg.

Parsons, T. \& V.M. Lidz (1967). "Death in American Society", i Edwin Shneidman (red.): Essays in Self-Destruction. New York: Science House.

Parsons, T., R.C. Fox \& V.M. Lidz (1972). “The 'Gift of Life' and Its Reciprocation«. Social Research, 39 (3):367-415.

Petersen, A.B. \& A-L. Sommer (red.)(1998). Dødens rum. Odense: Odense Universitetsforlag.

Prior, L. (1989). The Social Organization of Death: Medical Discourse and Social Practices in Belfast. London: Macmillan.

Puckle, B. (1926). Funeral Customs. London: T. W. Laurie.

Ragon, M. (1983). "Functionalism and Death", i The Space of Death. Charlottesville, VA: University Press of Virginia.

Raunkiær, M. (2008). “Udviklingen af den palliative indsats i Danmark i perioden 19852001 og forestillinger om den gode død «. Sygeplejersken, 7:58-69.

Richardson, R. (1987). Death, Dissection and the Destitute: A Political History of the Corpse. London: Routledge \& Kegan Paul.

Riley, J.W. Jr. (1983). “Dying and the Meaning of Death: Sociological Inquiries«. Annual Review of Sociology, 9:191-216.

Sartre, J.-P. (1965). Med døden i hjertet. København: Vintens Forlag.

Saunders, C. et al. (1981). Hospice: The Living Idea. London: Edward Arnold.

Schneider, W. (2006). “Das 'Gute Sterben' - Neue Befunde der Thanatosoziologie«. Soziologische Revue, 29 (4):425-434.

Seale, C. (1998). Constructing Death: The Sociology of Dying and Bereavement. Cambridge: Cambridge University Press.

Sommer, A.-L. (2003). De dødes haver - den moderne storbykirkegård. Odense: Syddansk Universitetsforlag.

Sudnow, D. (1967). Passing On: The Social Organization of Dying. Englewood Cliffs, NJ: Prentice-Hall.

Tamm, D. (1992). Dødens triumf-mennesket og døden $i$ Vesteuropa fra middelalderen til vore dage. København: Gad.

Unruh, D.R. (1981). “Is There a Sociology of Death?«. Contemporary Sociology, 10 (4):508-512. 
Vejlgaard, T.B., P. Sjøgren \& R. Maagaard (2007). “Organisering og udvikling af den palliative indsats i Danmark«. Ugeskrift for læger, 169 (44):3737-3739.

Vernon, G.M. (1970). The Sociology of Death. New York: The Ronald Press.

Vovelle, M. (1980). "Rediscovery of Death Since 1960«. Annals of the American Academy of Political and Social Science, 447:89-99.

Vovelle, M. (1983). La mort et l'Occident de 1300 à nos jours. Paris: Gallimard.

Walter, T. (1993). "Sociologists Never Die: British Sociology and Death", i David Clark (red.): The Sociology of Death. Padstow: Blackwell.

Walter, T. (red.)(1999). The Mourning for Diana. Oxford: Berg.

Walter, T. (2008). “The Sociology of Death«. Sociology Compass, 2 (1):317-336.

Warner, W.L. (1959). The Living and the Dead: A Study of the Symbolic Life of Americans. New Haven: Yale University Press.

Weber, M. (1904-1905/1995). Den protestantiske etik og kapitalismens ånd. København: Nansensgades Antikvariat.

Whaley, J. (red.)(1981). Mirrors of Mortality: Studies in the Social History of Death. London: Europa.

Willmott, H. (2000). “Death, So What? Sociology, Sequestration and Emancipation«. Sociological Review, 48 (4):649-665. 